\title{
Determinants of Capital Structure:The Case in Vietnam*
}

\author{
Thu Minh Thi VU' ${ }^{1}$, Chung Quang TRAN², Duong Thuy DOAN 3 , Thang Ngoc LE \\ Received: July 03, 2020 Revised: July 25, 2020 Accepted: August 10, 2020
}

\begin{abstract}
This is a quantitative research, underpinned by the philosophy of natural science and deduction approach that examines the impact of the various aspects of corporate governance mechanism on the choice of capital structure of Vietnamese listed firms. We focus on the effect of factors such as the board size, the board independence, and especially different ownership structures, which include the managerial ownership, the state ownership, the concentrated ownership, and the foreign ownership. They are the main scopes of corporate governance and are supposed to be relevant to determine the corporate financing choice. To explain the causal relationship between factors, we construct the regression model and then test it by using different statistical method approaches, including the pooled OLS, the fixed effects model, and the random effects model. Data are collected from 336 firms with shares listed in the Ho Chi Minh City Stock Exchange in Vietnam, totaling 1583 observations. Overall, the results reveal that the board size, state ownership, and concentrated ownership have positive impact on the firm's capital structure, whereas foreign ownership appears to have negative influence on the capital structure. The research does not find evidence of a the correlation between board independence, managerial ownership and corporate capital struture.
\end{abstract}

Keywords: Corporate Governance, Board Size, Board Independence, Ownership Structure, Capital Structure

JEL Classification Code: G30, G32, G34

\section{Introduction}

Making decision on capital structure is one of the most crucial decisions of a business. It represents the way a firm chooses to finance its assets and decide the corporate cost of capital, affecting the firm's performance and hence, the firm's value. Theoretical and empirical research have been

\section{*Acknowledgements:}

This research is funded by the National Economics University (NEU), Hanoi, Vietnam. The authors thank anonymous referees for their contributions and the NEU for funding this research.

${ }^{1}$ First Author and Corresponding Author. Lecturer, School of Accounting and Auditing, National Economics University, Vietnam[Postal Address: 207 Giai Phong, Dong Tam, Hai Ba Trung, Hanoi, 113068, Vietnam] Email: vuminhthu.neu@gmail.com

${ }^{2}$ Lecturer,School of Accounting and Auditing, National Economics University,Vietnam.Email: chungtq0209@neu.edu.vn

${ }^{3}$ Lecturer, School of Accounting and Auditing, National Economics University, Vietnam. Email: duongdt36@gmail.com

${ }^{4}$ Lecturer, School of Accounting and Auditing, National Economics University, Vietnam. Email: thangle@neu.edu.vn

(c) Copyright: The Author(s)

This is an Open Access article distributed under the terms of the Creative Commons Attribution Non-Commercial License (https://creativecommons.org/licenses/by-nc/4.0/) which permits unrestricted non-commercial use, distribution, and reproduction in any medium, provided the original work is properly cited. concerned with two main questions centered on the topic of capital structure. They are: "What factors affect capital structure" and "How to determine the company's optimal capital structure". Although there are numerous studies and academic discussions over these two questions, answering them seems still challenging to management in practice as capital structure varies according to firms operating in different industries and contexts.

Prior research linked the concept of capital structure with corporate governance and proposed that corporate governance influences coporate financing decision. Not only one single feature of corporate governance, but normally a set of them were studied in the relationship with capital structure. The common corporate governance' components observed are the size, the components, the roles, and the duties of the board.

Following this research direction, our study aims to explore the causal relationship between the firms' capital structure and the corporate governance in the context of Vietnam. It is built on a large body of literature about firms' financing choices. It is well established that the corporate structure of capital is affected by numerous factors, including firm's governance system. However, each firm behaves in a different manner depending on the particular 
context in which it operates. Besides, previous reseach often paid much attention to the impact of scopes of corporate governance mentioned above, but little on that of ownership structure. Therefore, in this research, beside board size and independence, we focus more on the effect of different types of corporate ownership on firm's financing, including the managerial ownership, the concentrated ownership, the government ownership, and the foreign ownership.

This research adopts the positivist philosophy and deduction approach, using quantitative method to explore the causal correlation between main features of firm-level governance mechanism and corporate decision on capital structure in Vietnamese enterprises. Accordingly, the paper proceeds as follows: the literature review, the research method, the results and discussion, and the conclusion.

\section{Literature Review}

\subsection{Corporate Governance}

Previous theories views corporate governance through two main approaches: the narrow approach and the wider approach. From the narrow approach, agency theory and transaction-cost theory explain the concept of corporate governance based on the company shareholders' perspective. According to the agency theory, the root cause of corporate governance is the separation between the ownership right of the principal (the shareholders) and the control right of the agent (the board of directors) that creates information asymmetry between them. From this, agency problem arises thanks to the conflict of interests between the stockholders and the directors of the company.

Managers may seek to maximize their own interests or have viewpoints that contrast with the stockholders' about risks faced by their company. Likewise, transaction-cost theory also tries to elucidate firm's governance mechanism based on the same narrow perspective, but it used the different concept of "Opportunism". The theory proposed that directors are naturally opportunistic and they, therefore, opportunistically arrange their transactions (Glinkowska \& Kaczmarek, 2015). Consequently, a company is suggested to safeguard its transactions in question against the managers' opportunism hazard. Within agency and transaction cost theory's view, corporate governance is developed to solve the problem of "How can shareholders exert their control over the management to make sure that the directors will act for their best interest?" and has been quickly adopted worldwide. Anh, Thu and Quynh (2020) stated that "a good corporate governance is a good combination and arrangement of the board structure's elements in order to effectively resolve agency conflict as well as reduce information asymmetry".
Stakeholder theory, developed in the 1970's, views corporate governance through another lens. This theory considers the company an individual in society and interacts with other entities. The company's activities not only involve its shareholders and managers, but also affect other entities such as employees, customers, suppliers, creditors, and people. Therefore, the firm should have accountability and responsibility to all of these stakeholders. In other words, the company needs to balance the benefit of its owners and the interests of its stakeholders. Only by doing this can the company grow sustainably. Motivated by this argument, Monks and Minow (2011) and Tricker (2015) broadened the operational aspects of firm governance system by adding various participants to this concept and adopted this wider view to define and evaluate the corporate direction and performance.

\subsection{Capital Structure}

The term "Capital structure" is concerned about permanent pattern of financing built by a defined structure of long-term debts, owners' capial, and preferred stock. Prior studies often used financial structure and capital structure interchangeably. But they are completely different concepts. Financial structure represents the relation between all of the firm's liabilities and its total asset (Gitman, 2009). It is mesured by financial leverage ratio (the total debt divided by the total assets) while capital structure is a part of financial structure and measured by the long-term debt to equity ratio.

A number of theories try to explain the corporate capital structure. The traditional Miller and Modigliani approach (I \& II) and trade-off theory searched for the optimal pattern of capital structure, which provides sufficient capital for efficient and profitable operations. Among them, trade-off theory is considered to be the advanced one as it combines factors of the mordern market such as the tax shield's benefit of debt, the market value of the company, the cost of financial distress in order to elucidate the connection between the business's gearing level and its cost of capital (Watson \& Head, 2016).

Pecking-order theory approaches the concept in a different way, seeking to rank corporate financing in a pecking order based on the issue of information asymmetry. The theory argues that firms will choose to finance a new projects by its retained earnings first as retained earning financing will helps to minimize information asymmetry (Khan, Qu, Shah, Bah, \& Khan, 2020). After that, debts will be favored over equity finance thanks to it lower cost of interest. Therefore, it is reasonable that a profitable firm is more likely to substitute debts for its internal funds (Ferrarini, Hinojales, \& Scaramozzino, 2017; Myers, 1977; Suto, 2003). 


\subsection{The Impact of Corporate Governance on Capital Structure}

Morellec, Nikolov and Schürhoff (2012) suggested that, not only factors related to market friction (such as taxes, cost of financial distress, or refinancing cost), but also factors associated to the intensity of the conflict between the owners and managers can affect firm's decision on capital structure. In their study, they first confirmed the existence of this causal relationship and then developed a dynamic tradeoff model revealing that the heterogeneity of firm's capital structure can be structurally associated to its governance system.

According to Haque, Arun and Kirkpatrick (2011), controlling shareholders of a poorly-governed enterprise prefer debts over equity finance in order to maintain their absolute ownership and control right. Conversely, a firm with strong corporate governance system can help to reduce agency cost and improve the investors' confidence in the business' future performance. This finally enhances the firm's ability to obtain more equity capital, reducing its dependence on long-term liabilities and leading to the changes in the business' capital structure (Gompers, Ishii, \& Metrick, 2003).

Not only one single scope or feature of corporate governance can have influence on the firm's capital structure. Research by Haque, Arun and Kirkpatrick (2011) revealed that factors such as the firm-level governance index, the concentrated ownership, firm size, firm's growth opportunity and profitability have influences on the level of debt used in Thailand firms. In their paper, the index of firm-level governance is a combination of factors including the shareholders' right, the the board's composition, and the duties and accountability towards the corporate's other stakeholders.

\subsubsection{Size of the Board of Directs and Capital Structure}

The Board of Directors is an important component of the firm's governance system. The size of the company's board represents the total number of the company's directors, including executives and non-executives, who set the direction and oversee the business' activities. The harmony and consensus of members in the board of directors decide the firm's overall success, so the factor is supposed to be appropriate in determination of the corporate financing structure. Mixed results were found on the connection between the size of the board of directors and the capital structure. First of all, Jensen (1986) posited that a large size of the board of directors is more likely to mobilize, seek, and access more external financial resources, and thus, more debt will be used to finance the company's assets. Berger, Ofek and Yermack (1997) concluded in their research that capital struture of the business was positively correlated to board size. Similarly, Adams (2003) conducted a quantitative study and found that more directors on the board can reach better decisions and can more effectively monitor firms' overall operations. Research by Naseem, Zhang, Malik and Rehman (2017) also supported this result, while they studying listed companies in China. However, Lipton and Lorsch (1992) had a constrasting view that the smaller size of the board will help the company operate more effectively. To investigate the influence of board size on the capital structure, we propose the following hypothesis:

\section{H1: Board size has an effect on the capital structure}

\subsubsection{Board Independence and Capital Structure}

It is commonly believed that the appearance of nonexecutive directors in the board can mitigate the interest conflict between the firm shareholders and the managers as it helps to enforce more control over management's areas of performance, finance, and accountability (Rahman \& Saima, 2018). Without the supersivion of independent members in the board, it is easier for management to manipulate corporate reporting. They become more oppoturnistic, investing in projects for their self-interest rather than maximising the shareholders's wealth. Therefore, non-executive or independent directors can somehow has the effect on the firm's choice of financing. The presence of non-executive members may create pressure over managers, forcing them to be more responsible in making decision regarding debt borrowing and using.

Peng (2004) and Mura (2007) posited that non-executive directors' supervision role has a crucial role in ensuring the transparency and efficiency of debt using. Moreover, the expertise and external relationships held by independent members can help the company access to more cheaper sources loans and enhance the efficiency of debt utilization, improving firm profits. Therefore, the proposed hypothesis is as follows:

H2: The board independence has an impact on the capital structure

\subsubsection{Managerial Ownership and Capital Structure}

Managers' ownership is measured by the portion of shares they, their spouse and children hold. If managers are the shareholders at the same time, they are less likely to overspend resources or invest in inefffective projects. Managerial ownership, hence, is considered a convincing way to reduce conflicts of interest discussed by agency theory and is the 
key feature of the firm-level governance system. Jensen and Meckling (1976) supported this opinion by arguing that the more shares owned by managers leads to the larger amount of debt used by the business. Granado-Peiró and López Gracia (2017) added that, when the managers hold below 39.5\% of firm, their activities are aligned with the other owners' interests and the usage of debt increases as their shareholding increases. Nevertheless, after this particular turning-point, managers face the entrenchment and decrease the amount of long-term liabilities used by firm as they own more share in firm, allowing room for them to act in their own interests. To study the effect of managerial ownership on the capital structure decision, we proposed the following hypothesis:

\section{H3: Managerial ownership affects the capital structure}

\subsubsection{State Ownership and Capital Structure}

Government ownership is often associated with a high level of leverage. To avoid the dilution of state owner, stateowned firms tend to rely on borrowings rather than stock issuing (Dewenter \& Malatesta, 2001). In addition, the stateowned feature gives these firms the privilege to enjoy loan guarantees, either official or unofficial, allowing them to borrow at preferred rate of interest, which helps to reduce the risks of financial ditress. The trade-off theory supports the positive correlation between state ownership and the amount of debt used by business.

In the past, during the period of central planned economy, most of the Vietnamese firms belonged to the state. However, from the time of economic reforms in the 1980's to present, there has been a strong growth in the number of business with the diverse ownership structure. Especially, in the past five years, the Vietnamese government has made great efforts to divest its capital in a series of large companies across the country, creating opportunity for multiple types of ownership to participate in operating the company. However, it is undeniable that until now, the Vietnamese government still holds a large number of shares in big enterprises especially in electricity, oil and gas industry. This fact shows that the Vietnamese government still retains sizable control over a group of companies, and influences business decisions, including decisions on capital structure. The hypothesis is proposed as follows:

\section{H4: State ownership influences the capital structure}

\subsubsection{Foreign Ownership and Capital Structure}

Most studies suggest an inverse correlation between foreign ownership and the level of long-term liabilities by firms. Li, Yue and Zhao (2009) conducted a study with Chinese companies and showed that foreign owners negatively affect all leverage measures (the ratios by the total liabilities, short- term liabilities, and long-term liabilities divided by total assets, respectively). There are two grounds for this conclusion. Firstly, enterprises with high levels of foreign ownership have more diversified channels of financing than other enterprises thanks to their good reputation and relationships. Secondly, in China, foreign companies are subject to lower taxes than domestic companies. Thus, they tend to use less debt because they do not benefit from the tax shield effect. Huang, Lin and Huang (2011), investigating Chinese listed companies in the 5-year period (from 2002 and 2005) and reported similar results. However, in their research, they explained that foreign stockholders who are mainly institutional investors with better ability to oversee corporate management will help to control over-investment by managers or contribute to reducing agency costs incurred due to the agency conflicts. Therefore, foreign ownership and financial leverage can play an alternative role in controlling behaviors stemming from the managers' selfinterest. The hypothesis proposed is as follows:

H5: Foreign ownership has an impact on the capital structure

\subsubsection{Ownership concentration and Capital Structure}

Concentration of ownership represents a state when one or several shareholders, called major or large shareholders, own a majority share in a company, resulting in the concentration of voting and controlling right. Jalila and Devi (2012) argue that under the close supervision of major shareholders, managers must work for the benefit of the owners. Some studies on ownership concentration argued that large corporate owners of a company can have a positive impact on corporate disclosure policies and minimize agency issues. However, the others favour the idea that major shareholders have power to control over the information flow, acerbating the information asymmetry among parties involved. Stock holders who own the majority shares of a business do not want to share or lose their control, and they, therefore, will avoid issuing shares if they are optimistic about their business's prospect. In this case, ownership concentration can play a role in making decision on corporate structure of capital and the other way around (Céspedes, González, \& Molina, 2010).

\section{H6: Ownership concentration affects the capital structure}

\section{Research Method}

\subsection{Research Design}

This research applies the philosophy of natural science called positivism, which supports the view that there is one objective reality, which is singular and separate from 
consciousness (Saunders, Lewis, \& Thornhill, 2016). Accordingly, to investigate the effects of firm's governance system on its capital structure, we follow the approach of deduction, propose hypotheses and test them by fomulating the model with measurable variables. The following is some main steps of the study:

- Firstly, we proposed the research question regarding the influence of corporate governance on capital structure.

- Secondly, previous theories and empirical papers studying the correlation between key featurers of corporate governance mechanism and firm's capital structure are reviewed and analysed.Six hypotheses are then developed.

- In the next step, the suitable model is built and tested based on measurable data that have been collected for listed firms in Ho Chi Minh City stock exchange in Vietnam.

- Finally, findings are presented and discussed.

The research aims at explaining the impact of different components of firm governance on its decision on capital structure. In the previous section, the effect of the firm-level governance mechanism's features on capital structure of Vietnamese firms are forecast by the researchers. Below are the six hypotheses established to examine the connections:

H1: Board size affects the firm's capital structure

H2: The board independence has an impact on the capital structure

H3: Managerial ownership affects the capital structure

H4: State ownership influences the capital structure

H5: Foreign ownership affects the capital structure

H6: Ownership concentration affects the capital structure
To test these hypotheses, the research employs regression models (The pool OLS, the random effects model, and the fixed effects model). In addition to variables representing the size, the independence of the board, the managerial ownership, the government ownership, the large ownership and the foreign ownership, we also add three control variables: the firm size, profitability and growth opportunity to the model as previous studies also confirmed their effects on capital structure. Finally, the model is developed as follows:

$$
\begin{aligned}
\mathrm{DE}_{i t}= & \beta_{0}+\beta_{1} \mathrm{BS}_{i t}+\beta_{2} \mathrm{IDP}+\beta_{3} \mathrm{MOWN}_{i t}+\beta_{4} \mathrm{SOWN}_{i t}+ \\
& \beta_{5} \mathrm{FOWN}_{i t}+\beta_{6} \mathrm{LOWN}_{i t}+\beta_{7} \mathrm{FS}_{i t}+\beta_{8} \mathrm{ROA}_{i t} \\
& +\beta_{9} \mathrm{GROW}_{i t}+\varepsilon_{i t}
\end{aligned}
$$

Code and measurement of all the variables are summarised in the Table 1.

\subsection{Data Collection Method}

The data used in this research is the secondary data garthered from financial reports of listed enterprises in the Ho Chi Minh Stock Exchange. This is also the type of data consistent with the positivism philosopy and quantitative research design mentioned and analysed above.

In Vietnam, there are two stock exchanges named after the two largest cities in the country - the Ho Chi Minh Stock Exchange (HOSE) and the Hanoi Stock Exchange (HNX). HOSE is the bigger one, established in 2000. By the end of 2019, there were nearly 400 companies listed on the HOSE, with a total of over 70,000 million shares in terms of listed volume and over 3,000 billion Vietnam Dong in terms of market capitalization, accounting for more than $70 \%$ of Vietnamese GDP. Requirements for share of a company to be listed on the HOSE and HNX also differ:

Table 1: Variable Explanation

\begin{tabular}{|l|c|l|}
\hline Variables & Code & \multicolumn{1}{|c|}{ Measure } \\
\hline Capital Structure & DE & Long-term debt over owners's equity ratio (D/E ratio) \\
\hline Board size & BS & Total number of members in the board of directors \\
\hline Board independence & IDP & Total number of non-executive members in the director board \\
\hline Managerial ownership & MOWN & The total percentage of shares owned by managers, their spouses and children. \\
\hline State ownership & SOWN & The total percentage of shares owned by the government \\
\hline Foreign ownership & FOWN & The total percentage of shares owned by foreign investors \\
\hline Ownership concentration & LOWN & $\begin{array}{l}\text { Total holding proportion of shareholders who own from 5\% of the company's } \\
\text { stocks. }\end{array}$ \\
\hline Firm size & FS & The book value of total assets \\
\hline Profitability & ROA & The ratio of profit before tax over total assets \\
\hline Future growth opportunity & GROW & $\begin{array}{l}\text { Tobin's Q - The market value of equity plus book value of debts over the total } \\
\text { assets ratio. }\end{array}$ \\
\hline
\end{tabular}


- HOSE stipulates that listed company's charter capital must be of at least 120,000 million Vietnam Dong (Vietnamese currency), while the regulation of the HNX is only 30,000 million Vietnam Dong.

- Listed firms in the HOSE are required to have at least two consecutively profitable years with no accumulated loss up to the listing date and overdue debts for more than one year. The HNX has no request on this issue.

- A listed company listed in HOSE is required to disclose all of its debts to the Board of Directors, Supervisory Board, major shareholders, and related individuals; HNX does not request this.

- A firm listed in HOSE is required to have at least $20 \%$ of voting shares held by 300 minor shareholders, while a listed HNX firms needs only $15 \%$ of voting shares owned by 100 minor shareholders.

- If a HOSE listed firm violates its Stock Exchange's disclosure stipulations four times or more, the firm may be placed under special warning and strict supervision.

Although the number of enterprises listed on the HOSE accounts for only a small proportion of the total number of enterprises in the country, they are considered the largest and leading companies with representative corporate governance's characteristics for all businesses in the economy.

In addition, all financial statements of companies listed on HOSE are subject to be audited and supervised before they are disclosed to the public. Therefore, the quality of data collected including its validity and reliability is guaranteed. All research data is gathered from the annual audited financial statements of listed companies that are publicly available on the HOSE's official website.

The study uses the data set from enterprises that have stocks listed on HOSE for the period from 2015 to 2019. We exclude banks and financial companies (including insurance and security firms) from the sample. At the end, there are 336 listed firms included in the sample with 1583 obsevations.

\section{Data Analysis and Interpretation}

\subsection{Descriptive Statistics}

Table 2 shows the statistical description for max, min, mean and standard deviation value for variables employed in the model.

From 2015 to 2019, the capital structure, measured by the ratio $\mathrm{D} / \mathrm{E}$, has the maximum, minimum, and mean of $0,4.93$, and 0.68 , respectively. According to the Vietnamese Ministry of Finance, in general, Vietnamese firms have a relatively low level of $\mathrm{D} / \mathrm{E}$ ratio compared to firms in other countries of the same region. Also, this ratio has decreased compared to the previous period. One explanation for this limited use of loans in Vietnamese firms is the high rate of interest. While banks required an interest rate from $8 \%$ to $10 \%$ per annum for loans, firms can gain an average rate of return just from $6 \%$ to $8 \%$ for projects they invested. Therefore, the low level of profit generated from an investment cannot be afforded by expensive loans. Besides, frequent changes in macroeconomic policies and uncertainties in an emerging market's economic environment make banks reluctant to provide long-term credits. Moreover, from January 2016, companies in Vietnam need to keep their D/E ratio at appropriate level to be allowed to deduct interest expenses when determining corporate income tax. Specifically, if the $\mathrm{D} / \mathrm{E}$ ratio of a business is more than five times that of the manufacturing sector and more than four times that of the remaining sectors, the excess amount of interest expense should not be considered as the reasonable expense to determine the income tax. This is also the reason why the maximum value of $\mathrm{D} / \mathrm{E}$ ratio for listed firms stands at 4.93 for the period. Instead of long-term debts, Vietnamese firms are also actively seeking alternative sources to finance their assets, including the equity capital and the short-term liabilities, which account for $50 \%$ to $90 \%$ of their total debt finance.

Table 2: Statistic Description of Variables

\begin{tabular}{|l|c|c|c|c|c|}
\hline & $\mathbf{N}$ & Minimum & Maximum & Mean & Std. Deviation \\
\hline DE & 1583 & 0.00 & 4.93 & 0.68 & 0.87 \\
\hline BS & 1583 & 3.00 & 11.00 & 5.69 & 1.29 \\
\hline IDP & 1583 & 0.00 & 10.00 & 3.85 & 1.42 \\
\hline SOWN & 1583 & 0.00 & 97.00 & 15.76 & 25.11 \\
\hline FOWN & 1583 & 0.00 & 77.58 & 14.53 & 16.16 \\
\hline LOWN & 1583 & 0.00 & 100.00 & 51.08 & 23.24 \\
\hline MOWN & 1583 & 0.00 & 73.12 & 5.90 & 11.18 \\
\hline FS* & 1583 & 128,000 & $287,974,177$ & $4,776,930$ & $14,507,629$ \\
\hline ROA & 1583 & -0.78 & 0.92 & 0.10 & 0.09 \\
\hline Tobin's Q & 1583 & 0.09 & 9.04 & & 0.22 \\
\hline
\end{tabular}

*Unit: Million VND Dong 
Board size is measured by the number of executive and non-executive members on the board. Company Law in Vietnam requires at least three members and a maximum of 11 members in the board of director. An average of 6 members is lower than 10 directors of non-financial firms in Thailand, Spain and nine directors in the US and China (Detthamrong, Chancharat \& Vithessonthi, 2017; Granado Peiró \& López Gracia, 2017; Kieschnick, \& Moussawi, 2018; Vijayakumaran \& Vijayakumaran, 2019). Having developed from centrallyplanned economy, Vietnamese firms are highly characterized by stated-owned ownership and high ownership concentration. This explains why there still exist firms whose majority of shares is owned by the government or large shareholders (up to $97 \%$ share owned by the government and $100 \%$ share owned by major shareholders), signifying the controlling role of the government or large owners in those companies. However, the mean of the percentage of shares owned by the Vietnamese government in listed firms for this period is nearly $16 \%$, which is much lower than the previous time (39\%-43\% during the period from 2005 to 2012). This decrease proves the strong efforts of the Vietnamese government in reducing its direct control and command in order to establish a multisectoral commodity economy regulated by the market (Tran, Nonneman, \& Jorissen, 2014). One more noticeable change for the period studied in the research can be seen at the propotion of firms' shares owned by foreign investors. The highest rate held by them is nearly $78 \%$ with an average of $16 \%$, which doubles the figure for the period of 2007-2015 (Vo, 2017). This is thanks to the removal of the foreign ownership cap by the Vietnamese government in 2015 in order to encourage more and more foreign capital to be poured into the developing market.

\subsection{Results and Discussion}

Table 3 shows the correlation matrix among variables and VIF indexes, respectively. As all of VIF indexes are generally smally than 5, we can conclude that the problem of severe multicollinearity

among varibles does not exist.

To find the best fit model, the pooled OLS, fixed effects and random effects models are compared. F-test and Hausman test evidently that fixed effects model is the most suitable among these. Overall, board size (BS), state ownership (SOWN), and concentrated or large ownership (LOWN) are found to have positive impact on capital structure (DE), whereas foreign ownership (FOWN) appears to have negative impact on capital structure (DE). The hypotheses $\mathrm{H} 1, \mathrm{H} 4, \mathrm{H} 5$, and $\mathrm{H} 6$ are accepted.

In details, more members in the board of director means more long-term debt on the company's books. An additional member to the board can create more chances for the business to access multiple sources of long-term liabilites with low cost. This benefit motivates firms to use more debt instead of equity finance (Anderson, Mansi, \& Reeb, 2004). Jensen (1986) also supported the positive correlation between the size of the board of directors and debt to equity ratio and explained this relationship based on agency theory. He proposed that the board becomes more effective as it increases in size and that higher level of leverage is an effective mechanism to reduce agency conflict and hence, reduce agency cost of free cash flows. Similarly, Adams (2003) posited that larger board can reduce agency conflict by enhacing decision making and mornitoring management in a better way. The significant and positive influence of

Table 3: CorrelationBetween Variables

\begin{tabular}{|l|c|c|c|c|c|c|c|c|c|c|c|}
\hline & DE & BS & IDP & SOWN & FOWN & LOWN & MOWN & FS & ROA & $\begin{array}{c}\text { Tobin's } \\
\text { Q }\end{array}$ & $\begin{array}{c}\text { VIF } \\
\text { Index }\end{array}$ \\
\hline DE & 1 & & & & & & & & & & \\
\hline BS & -0.035 & 1 & & & & & & & & & 2.30 \\
\hline IDP & $-.109^{* *}$ & $.683^{* *}$ & 1 & & & & & & & & 2.25 \\
\hline SOWN & -0.028 & $-.100^{* *}$ & -0.03 & 1 & & & & & & & 1.35 \\
\hline FOWN & $-.169^{* *}$ & $.395^{* *}$ & $.267^{* *}$ & $-.115^{* *}$ & 1 & & & & & & 1.25 \\
\hline LOWN & 0.035 & -0.028 & $.103^{* *}$ & $.412^{* *}$ & 0.019 & 1 & & & & & 1.29 \\
\hline MOWN & $.117^{* *}$ & -0.01 & $-.257^{* *}$ & $-.272^{* *}$ & -0.051 & $-.074^{* *}$ & 1 & & & & 1.25 \\
\hline FS & $.140^{* *}$ & $.214^{* *}$ & $.194^{* *}$ & $.080^{* *}$ & $.097^{* *}$ & $.074^{* *}$ & $-.071^{* *}$ & 1 & & & 1.08 \\
\hline ROA & $-.278^{* *}$ & $.079^{* *}$ & $.111^{* *}$ & 0.044 & $.164^{* *}$ & $.090^{* *}$ & -0.02 & -0.004 & 1 & & 1.62 \\
\hline Tobin's Q & $-.163^{* *}$ & $.120^{* *}$ & $.188^{* *}$ & $.059^{*}$ & $.213^{* *}$ & $.215^{* *}$ & $-.057^{*}$ & $.130^{* *}$ & $.620^{* *}$ & 1 & 1.75 \\
\hline
\end{tabular}


Table 4: Regression Results

\begin{tabular}{|c|c|c|c|c|c|c|c|c|}
\hline & \multicolumn{2}{|c|}{ Pooled OLS } & \multicolumn{2}{|c|}{ Fixed Effects (FEM) } & \multicolumn{2}{|c|}{ Random Effects (REM) } & \multicolumn{2}{|c|}{ Robust FEM } \\
\hline & Coeff. & Std. Error & Coeff. & Std. Error & Coeff. & Std. Error & Coeff. & Std. Error \\
\hline BS & $0.0891^{* * *}$ & 0.0301 & $0.0406^{* *}$ & 0.0274 & $0.053^{* *}$ & 0.0253 & $0.0406^{\star *}$ & 0.3230 \\
\hline IDP & $-0.0990^{*}$ & 0.0269 & -0.0269 & 0.0225 & -0.041 & 0.0212 & -0.0269 & 0.3110 \\
\hline SOWN & $0.0025^{\star *}$ & 0.0012 & $0.0014^{* *}$ & 0.0010 & $0.002^{*}$ & 0.0010 & $0.0014^{* *}$ & 0.0013 \\
\hline FOWN & $-0.0100^{* * *}$ & 0.0018 & $-0.0153^{* * *}$ & 0.0020 & $-0.0138^{* * *}$ & 0.0020 & $-0.0153^{* * *}$ & 0.0040 \\
\hline LOWN & $0.0035^{\star * \star}$ & 0.0013 & $0.0046^{*}$ & 0.0013 & $0.0019^{*}$ & 0.0011 & $0.0046^{*}$ & 0.0017 \\
\hline MOWN & $0.0066^{* *}$ & 0.0026 & -0.0015 & 0.0031 & 0.0033 & 0.0027 & -0.0015 & 0.0053 \\
\hline FS & $9.26 \mathrm{E}-09^{* * *}$ & 1.87E-09 & $3.9 \mathrm{E}-10^{*}$ & 2.54E-09 & $2.89 \mathrm{E}-09^{* *}$ & 2.10E-09E & $3.9 \mathrm{E}-10^{*}$ & 4.55E-09 \\
\hline ROA & $-3.0718^{\star \star *}$ & 0.3460 & $-1.519^{* * *}$ & 0.2360 & $-1.703^{* * *}$ & 0.2280 & $-1.519^{* * *}$ & 0.4470 \\
\hline Tobins'Q & 0.040 & 0.0440 & 0.0440 & 0.0400 & 0.0197 & 0.0352 & 0.0440 & 0.0393 \\
\hline R-Square & \multicolumn{2}{|c|}{0.2326} & \multicolumn{2}{|c|}{0.2458} & \multicolumn{2}{|c|}{0.2416} & & \\
\hline Observations & \multicolumn{2}{|c|}{1583} & & & \multicolumn{2}{|c|}{1583} & & \\
\hline F-test & \multicolumn{8}{|c|}{$20.08^{* * *}$} \\
\hline \multicolumn{3}{|l|}{ Hausman Test } & \multicolumn{4}{|c|}{$19.84^{* * *}$} & & \\
\hline \multicolumn{3}{|c|}{ Chi square (X2) (Heterokedasticity) } & \multicolumn{4}{|c|}{$312.86^{* * *}$} & & \\
\hline
\end{tabular}

board size on firm's leverage level was confirmed by various studies, suggesting that board size (BS) may be one crucial determinant of the corporate capital structure (Naseem, Zhang, Malik, \& Rehman, 2017; Bokpin \& Arco, 2009).

For state ownership, the paper's finding also confirms the proposed hypothesis. Debt finance is revealed to be positively associated with the business' state ownership. As analyzed above, state-owned firms have some privileges over other firms regarding their ability to access finance sources. They can find funding for their assets without much effort. It is because loans guaranteed by the State are considered much more secure for creditors. In addition, the Vietnamese government is the controlling shareholder of most of the banks, so the inter-relationships between state-owned firms and banks are much strengthened (Bhabra, Liu, \& Tirtiroglu, 2008). Thanks to this advantage, it is likely that state-owned companies in Vietnam have a low level of financial distress cost and a high level of long-term debt finance.

Large ownership or concentrated ownership represents total proportion of shared held by shareholders who own more than 5\% share of firm. A strongly positive association between controlling owner's holdings and level of debt is supported by this research. Céspedes, González, and Molina (2010) argued that firms with highly concentrated ownership tend to avoid issuing shares as it is the threat of controlling dilution. Foreign ownership is the only factor studied to be inversely correlated to the capital structure. The finding is consistent with most of the studies supporting this negative relationship (Huang, Lin, \& Huang, 2011; Li, Yue, \& Zhao, 2009). According to the results of statistical method approaches, we do not find evidence for the influence of managers' shareholding and the independence of the board of directors on firm's choice of capital structure (see Table 4).

\section{Conclusion}

This is a quantitative research underpinned by the philosophy of positivism and deduction research design to explain the causal correlation between firm-level governance and the choice of capital structure of listed companies in Vietnam. Our results show that the size of the board of directors, state ownership, ownership concentration, and foreign holding might be the good determinants of capital structure for Vietnamese listed companies.

\section{References}

Adams, R. (2003). Is corporate governance different for bank holding companies? Economic Policy Review - Federal Reserve Bank of New York, 9(1), 123-142. https://doi.org/10.2139/ ssrn.387561

Anderson, R., Mansi, S., \& Reeb, D. (2004). Board characteristics, accounting report integrity, and the cost of debt. Journal of Accounting and Economics, 37(3), 315-342. https://doi. org/10.1016/j.jacceco.2004.01.004 
Anh,N., Thu,V.,\& Quynh,D.(2020). Corporate Governance and Stock Price Synchronicity: Empirical Evidence from Vietnam. International Journal of Financial Studies,8(2), 1-13. https:// doi.org/10.3390/ijfs8020022

Berger,P., Ofek, E., \& Yermack, D. (1997). ManagerialEntrenchment and Capital Structure Decisions. The Journal of Finance, 52(4), 1411-1438. https://doi.org/10.1111/j.1540-6261.1997. tb01115.x

Ferrarini, B., Hinojales, M., \& Scaramozzino, P. (2017). Chinese Corporate Leverage Determinants. Journal of Asian Finance, Economics and Business, 4(1), 5-18. http://dx.doi.org/10.13106/ jafeb.2017.vol4.no1.5

Bhabra, H. S., Liu, T., \& Tirtiroglu, D. (2008). Capital structure choice in a nascent market, evidence from listed firms in China. Financial Management, 37(2), 341-364. https://doi. org/10.1111/j.1755-053X.2008.00015.x

Bokpin, G., \& Arko, A. (2009). Ownership structure, corporate governance and capital structure decisions of firms. Studies in Economics and Finance, 26(4), 246-256. https://doi. org/10.1108/10867370910995708

Céspedes, J., González, M., \& Molina, C. (2010). Ownership and capital structure in Latin America. Journal of Business Research, 63(3), 248-254. https://doi.org/10.1016/j.jbusres.2009.03.010

Detthamrong, U., Chancharat, N., \& Vithessonthi, C. (2017). Corporate governance, capital structure and firm performance: Evidence from Thailand. Research in International Business and Finance, 42, 689-709. https://doi.org/10.1016/j. ribaf.2017.07.011

Dewenter, K., \& Malatesta, P. (2001). State-owned and privatelyowned firms: An empirical analysis of profitability, leverage, and labor intensity. The American Economic Review, 91(1), 320-334. https://doi.org/10.1257/aer.91.1.320

Gitman, L. (2009). Principles of managerial finance (12th ed.). London, UK: Pearson Prentice Hall.

Glinkowska, B., \& Kaczmarek, B. (2015). Classical and modern concepts of corporate governance (Stewardship Theory and Agency Theory). Management, 19(2), 84-92. https://doi. org/10.1515/manment-2015-0015

Gompers, P., Ishii, J., \& Metrick, A. (2003). Corporate Governance and Equity Prices. The Quarterly Journal of Economics, 118(1), 107-155. https://doi.org/10.1162/00335530360535162

Granado-Peiró, N., \& López-Gracia, J. (2017). Corporate Governance and Capital Structure: A Spanish Study. European Management Review, 14(1), 33-45. https://doi.org/10.1111/ emre. 12088

Haque, F., Arun, T., \& Kirkpatrick, C. (2011). Corporate governance and capital structure in developing countries: A case study of Bangladesh. Applied Economics, 43(6), 673-681. https://doi. org/10.1080/00036840802599909

Huang, B. Y., Lin, C. M., \& Huang, C. M. (2011). The Influences of Ownership Structure: Evidence from China. The Journal of Developing Areas, 45(1), 209-227. https://doi.org/10.1353/ jda.2011.0003
Jalila, S., \& Devi, J. (2012). Ownership Structure Effect on the Extent of Segment. Disclosure: Evidence from Malaysia. Procedia Economics and Finance, 2, 247-256. https://doi. org/10.1016/S2212-5671(12)00085-8

Jensen, M. (1986). Agency Costs of Free Cash Flow, Corporate Finance, and Takeovers. The American Economic Review, 76(2), 323-329. http://dx.doi.org/10.2139/ssrn.99580

Jensen, M. C., \& Meckling, W. H. (1976). Theory of the firm: Managerial behavior, agency costs and ownership structure. Journal of Financial Economics, 3(4), 305-360. https://doi. org/10.1016/0304-405X(76)90026-X

Khan, K.,Qu, J.,Shah, M. H., Bah, K.,\&Khan, I. U. (2020). Do Firm Characteristics Determine Capital Structure of Pakistan Listed Firms? A Quantile Regression Approach. Journal of Asian Finance, Economics and Business, 7(5), 61-72. https:// doi.org/10.13106/jafeb.2020.vo17.no5.061

Kieschnick, R., \& Moussawi, R. (2018). Firm age, corporate governance, and capital structure choices. Journal of Corporate Finance, 48, 597-614. https://doi.org/10.1016/j. jcorpfin.2017.12.011

Li, K., Yue, H., \& Zhao, L. (2009). Ownership, institutions, and capital structure: Evidence from China. Journal of Comparative Economics, 37(3), 471-490. https://doi.org/10.1016/j. jce.2009.07.001

Lipton, L.,\& Lorsch, J. (1992). A Modest Proposal for Improved Corporate Governance. The Business Lawyer, 48, 59-77. https:// www.jstor.org/stable/pdf/40687360.pdf?seq=1

Rahman, M. M., \&SaimaF.N. (2018). Efficiency of Board Composition on Firm Performance: Empirical Evidence from listed Manufacturing Firms of Bangladesh. Journal of Asian Finance, Economics and Business, 5(2), 53-61. https://doi. org/10.13106/jafeb.2018.vol5.no2.53

Monks, R. A. G.,\& Minow, N. (2011). Corporate governance(5th ed.). West Sussex, UK: John Wiley \& Sons. https://doi. org/10.1002/9781119207238

Morellec, E., Nikolov, B., \& Schürhoff, N. (2012). Corporate Governance and Capital Structure Dynamics. Journal of Finance, 67(3), 803-848. https://doi.org/10.1111/j.15406261.2012.01735.x

Mura, R. (2007). Firm performance: Do non-executive directors have minds of their own? Evidence from UK panel data. Financial Management, 36, 81-12. https://doi.org/10.1111/ j.1755-053X.2007.tb00082.x

Myers, S. C. (1977). Determinants of corporate borrowing. Journal of Financial Economics, 5, 147-175. https://doi. org/10.1016/0304-405X(77)90015-0

Naseem, M. A., Zhang, H., Malik, F., \& Rehman, R. U. (2017). Capital Structure And Corporate Governance. The Journal of Developing Areas, 51(1), 33-47. https://doi.org/10.1353/ jda.2017.0002

Peng, M. (2004). Outside Directors and Firm Performance during Institutional Transitions. Strategic Management Journal, 25(5), 453-471. https://doi.org/10.1002/smj.390 
Saunders, M., Lewis, P., \& Thornhill, A. (2016). Research methods for business students (7th ed.). Harlow, UK: Pearson.

Suto, M. (2003). Capital Structure and Investment Behaviour of Malaysian Firms in the 1990s: A study of corporate governance before the crisis. Corporate Governance, 11(1), 25-39. https:// doi.org/10.1111/1467-8683.00299

Tran, N. M., Nonneman, W., \& Jorissen, A. (2014). Government ownership and firm performance: The case of Vietnam. International Journal of Economics and Financial Issues, 4(3), 628-650. https://doi.org/10.1108/mrr-03-2019-0136

Tricker, R.I. (2015). Corporate governance: Principles, policies, and practices (3rd ed.). New York, NY: Oxford University Press.
Vijayakumaran, S., \& Vijayakumaran, R. (2019). Corporate Governance and Capital Structure Decisions: Evidence from Chinese Listed Companies. Journal of Asian Finance, Economics and Business, 6(3), 67-79. https://doi.org/10.13106/ jafeb.2019.vol6.no3.67

Vo, X. (2017). Determinants of capital structure in emerging markets: Evidence from Vietnam. Research in International Business and Finance, 40, 105-113. DOI: 10.1016 ribaf.2016.12.001

Watson, D., \& Head, A. (2016). Corporate finance: Principles and practice (7th ed.). Harlow, UK: Pearson Education Limited. 